\title{
ОЦЕНКА РАЗВИТИЯ ИПОТЕЧНОГО ЖИЛИЩНОГО КРЕДИТОВАНИЯ ПО ДАННЫМ МСФО ЗА 2015-2017 ГГ.
}

\author{
(c) 2019 Савинова Валентина Андреевна \\ доктор экономических наук, профессор \\ Самарский государственный экономический университет, Россия, Самара \\ E-mail: savinovava@yandex.ru \\ (c) 2019 Потешкина Валерия Валерьевна \\ магистрант \\ Самарский государственный экономический университет, Россия, Самара \\ E-mail:1997@mail.ru
}

Рассматриваются основы международных стандартов финансовой отчетности в деятельности коммерческих структур, обосновывается необходимость их применения.

Ключевые слова: МСФО, стандартизация, международные стандарты, финансовая отчетность, банковская система.

Рыночная экономика создает объективные основы формирования совокупности финансово-кредитных отношений в финансовой системе государства. Важнейшим элементом финансово-кредитных отношений выступает банковская система. В условиях финансовой глобализации она приобретает все более интеграционный характер.

На сегодня основным стратегическим направлением для России является реализация программы по выводу страны на общемировые параметры уровня и качества жизни населения, среди которых решающее место отводится обеспечению населения доступным и комфортным жильем. Мировое сообщество рассматривает в качестве механизма решения данной задачи ипотечное жилищное кредитование.

Ипотечное жилищное кредитование определяется как наиболее сложный кредитный продукт в совокупности кредитных отношений. Организационно он включает два блока взаимосвязанных операций:

1) непосредственно ипотечное кредитование населения и хозяйствующих субъектов;

2) уступку прав на кредитные требования ипотечным агентствам на цели формирования кредитных ресурсов для кредитования заемщиков.

Таким образом, под ипотечным кредитованием понимается система экономических отношений по предоставлению кредита под залог недвижимости, а также рефинансирование кредитов кредитно-финансовыми институтами.
В связи с этим ипотечный кредит выполняет важную функцию в замещении государственных источников финансирования в жилищном строительстве банковским кредитом. Его развитие способствует наращиванию инвестиционной активности экономических субъектов, что особенно важно в условиях дефицита кредитных ресурсов долгосрочного характера и высоких темпов инфляции.

Общие положения функционирования ипотечного жилищного кредитования на уровне мировых стандартов достаточно широко используются отдельными странами, однако его организация в каждой из них отличается своей спецификой. Это обусловливается различиями в их общественно-экономическом развитии, в формировании финансово-кредитной системы, исторического и современного банковского законодательства и др.

Процессы глобализации мирового хозяйства, в том числе и финансовых рынков, обусловили существенные изменения в системе его регулирования. Значительная роль в данных процессах отводится проблеме унификации учета и отчетности. Развитие бизнес-процессов в условиях возрастания роли международной интеграции в сфере экономики обусловили необходимость формирования однотипного и прозрачного подхода к условиям и принципам финансового учета и отчетности, применяемым в различных странах. В этой связи мировым сообществом были признаны неким эталоном формирования и предоставления финансовой отчетности орга- 
низаций - «Международные стандарты финансовой отчетности (МСФО)».

В связи с тем, что стандарты бизнеса и ведение учета могут отличаться как от компании к компании, так и на уровне различных стран, МСФО были созданы для того, чтобы иметь «общий язык» бухгалтерского учета.

Таким образом, Международные стандарты финансовой отчетности (МСФО) - это набор международных стандартов бухгалтерского учета, в которых указываются каким образом конкретные виды операций и другие события должны отражаться в финансовой отчетности. В этой связи важное место отводится достоверности финансовой отчетности и информации пользователей о финансово-хозяйственной деятельности.

Можно привести и другие определения международным стандартам финансовой отчетности. Так, на наш взгляд, наиболее содержательным представляется определение T.В. Парамоновой, рассматривающей международные стандарты как «наднациональные стандарты, как единый свод понятных и имеющих юридическую силу глобальных и универсальных стандартов финансовой отчетности для того, чтобы помочь участникам в условиях различных рынков капитала... принимать правильные экономические решения» [1].

МСФО публикуются Советом по международным стандартам финансовой отчетности, и они точно определяют, каким образом специалисты должны вести и презентовать бухгалтерские счета. Целью МСФО является поддержание стабильности и прозрачности в финансовом мире. Это позволяет предприятиям и индивидуальным инвесторам принимать квалифицированные финансовые решения, поскольку они могут точно видеть, что происходит с компанией, в которую они хотят инвестировать.

В 1973 году рядом стран был создан Комитет по международным стандартам финансовой отчетности, правопреемником которого в последствие стал Совет по международным стандартам финансовой отчетности.

В 1979 году Комитетом по МСФО заинтересовались и другие организации: комиссия по ценным бумагам США, международная организация по ценным бумагам и др. При этом МВФ и Совет министров стран «Большой семерки» одобрили его предложения по стандартам бухгалтерской отчетности в 1999 г.
Таким образом, постепенно у международного сообщества формировался интерес к международным стандартам финансовой отчетности и желание разговаривать «на одном финансовом языке».

Основными объективными причинами перехода России на международные стандарты финансовой отчетности можно назвать следующие:

1. Применение международных стандартов дает возможность сравнивать между собой результаты финансовой деятельности экономических субъектов различных стран.

2. Внутри страны центральный банк, правительственные учреждения и другие пользователи финансовой информации получают возможность эффективно сравнивать между собой различные секторы экономики.

3. Нерезиденты активно могут заниматься масштабной коммерческой деятельностью в какой-либо стране, если имеют возможность оценить сложившиеся в этой стране финансовоэкономические условия. С этой целью им должны быть предоставлены все условия для получения адекватной финансовой информации, т.е. информации, основанной на МСФО.

4. Страны, вступив в мировое экономическое сообщество, включаются в процесс интенсивных переговоров по экономическим вопросам... Одним из важнейших условий успеха таких переговоров является сопоставимость данных о финансовой деятельности, обеспечить которую практически невозможно без применения МСФО. [2]

Сегодня использование МСФО крупными корпорациями в своей деятельности обеспечивает им большую открытость и как результат большую информативность данных. Это обеспечивает компании более высокий рейтинг и повышает ее конкурентоспособность.

До недавнего времени формирование российскими банками финансовой отчетности в формате МСФО носило добровольный характер и служило элементом престижа. Как правило, такую отчетность внешние аудиторы готовили один раз в год. По данным Центрального банка Российской Федерации, ежегодную отчетность по международным стандартам (с помощью внешних аудиторов) к началу 2000года составляли не более 130 российских банков [3].

В России переход экономики на международные стандарты произошел в 2004 году. Од- 
ним из первых был банковский сектор. С этого времени в России коммерческие банки стали параллельно формировать два вида финансовой отчетности: во-первых, отчетность по российским правилам бухгалтерского учета и, во-вторых, отчетность на основе международных стандартов. Таким образом, на основе применения МСФО в деятельности коммерческих банков было положено начало активному сближению и гармонизации отечественных и международных норм учета и отчетности кредитных организаций. Это ознаменовало новый этап в развитии банковской системы России.

Данный этап в формировании финансовой отчетности отличался тем, что при составлении финансовой отчетности использовались правила, соответствующие как нормам российского законодательства, так и нормативным актам Банка России. Только после этого формируется отчетность, выполненная на основе международных стандартов. Такая процедура формирования финансовой отчетности осуществляется в целях ее объективности и сопоставимости с другими показателями.

В данной работе на примере ПАО Сбербанк проведен анализ развития ипотечного жилищного кредитования по данным МСФО.
ПАО Сбербанк России одним из первых на российском рынке освоил ипотечное жилищное кредитование под залог недвижимого имущества. На сегодняшний день Сбербанк является лидером ипотечного жилищного кредитования, сохраняя и постоянно оптимизируя линейку кредитных продуктов (табл. 1).

Следует также отметить, что Сбербанк России первым отменил дополнительные комиссии по ипотечным кредитам. Банк постоянно смягчает требования к заемщикам и активно наращивает объемы кредитования. Сбербанк предлагает клиентам выгодные и разнообразные программы жилищного кредитования.

В структуре кредитных продуктов ПАО Сбербанк ведущую позицию занимает ипотечное жилищное кредитования. Именно этим мотивируется выбор объекта исследования на основе МСФО в данном исследовании.

В этих целях рассмотрены соотношения долей отдельных видов кредитов в их совокупности (табл. 2). Из данных таблицы видно, что ипотечное жилищное кредитование лидирует в структуре кредитных продуктов ПАО Сбербанк и занимает на последнюю дату более $63,5 \%$ от общего объема кредитных продуктов.

Таблица 1. Рейтинг кредитных организаций РФ по величине активов

\begin{tabular}{|c|c|c|c|}
\hline № & Наименование банка & Место в рейтинге & Величина активов, млн. руб \\
\hline 1. & ПАО Сбербанк & 1 & 26724414 \\
\hline 2. & ВТБ & 2 & 13254312 \\
\hline 3. & Газпромбанк & 3 & 6127358 \\
\hline 4. & Россельхозбанк & 4 & 3242629 \\
\hline 5. & Альфа-банк & 5 & 3129392 \\
\hline
\end{tabular}

Источник: Центральный банк РФ. Финансовые результаты деятельности кредитных организаций [Электронный ресурс].Режим доступа: http://www.cbr.ru/region/IndikatorTable?region=RUSS Indikator=Tablel.12 year (дата обращения: 15.11.2018)

Таблица 2. Структура кредитных продуктов ПАО Сбербанк

\begin{tabular}{|l|c|c|c|c|c|c|}
\hline \multirow{2}{*}{ Показатели } & \multicolumn{2}{|c|}{01.01 .2016} & \multicolumn{2}{c|}{01.01 .2017} & \multicolumn{2}{c|}{01.012018} \\
\cline { 2 - 7 } & $\begin{array}{c}\text { Сумма, } \\
\text { млрд. руб. }\end{array}$ & $\begin{array}{c}\text { Доля, } \\
\%\end{array}$ & $\begin{array}{c}\text { Сумма, } \\
\text { млрд. руб. }\end{array}$ & $\begin{array}{c}\text { Доля, } \\
\%\end{array}$ & $\begin{array}{c}\text { Сумма, } \\
\text { млрд. руб. }\end{array}$ & $\begin{array}{c}\text { Доля, } \\
\%\end{array}$ \\
\hline $\begin{array}{l}\text { Ипотечное жилищное } \\
\text { кредитование }\end{array}$ & 2554,6 & 58,6 & 2751,9 & 61,9 & 3189,7 & 63,5 \\
\hline $\begin{array}{l}\text { Потребительские и прочие } \\
\text { ссуды }\end{array}$ & 1681,8 & 38,2 & 1574,3 & 35,4 & 1725,0 & 36,1 \\
\hline Автокредитование & 142,0 & 3,2 & 119,8 & 0,3 & 121,2 & 0,4 \\
\hline Итого: & 4378,4 & 100,0 & 4444,8 & 100,0 & 5037,7 & 100,0 \\
\hline
\end{tabular}


Ипотечное жилищное кредитование остается приоритетным направлением деятельности ПАО Сбербанк (табл. 3).

ПАО Сбербанк по-прежнему занимает лидирующие позиции в большинстве субъектов Российской Федерации по ипотечному кредитованию, его доля на рынке ипотечных кредитов составляет более $60 \%$ (рис. 1).

В развитии кредитных банковских операций важное место отводится формированию структуры ссудной задолженности и ее оптимизации (табл. 4). По данным таблицы видно, что объёмы кредитования физических лиц в ПАО Сбербанк растут за счёт увеличения доли непросроченных ссуд, а также за счёт снижения доли просроченных ссуд. На рост объёмов кредитования физических лиц оказывает непосредственное влияние тенденция снижения величины процентной ставки. В 2018 году процентная ставка достигла рекордного минимума и составила $9,75 \%$.

Можно выявить основные достоинства ипотечного кредитования в Сбербанке. Во-первых, банк ограничил максимальный возраст заемщиков пенсионным возрастом до 75 лет.

Таблица 3. Динамика развития ипотечного жилищного кредитования ПАО Сбербанк за $2016-2017$ гг.

\begin{tabular}{|l|c|c|c|}
\hline \multicolumn{1}{|c|}{ Показатели } & 2016 & 2017 & Темп роста,\% \\
\hline $\begin{array}{l}\text { 1. Доля ПАО Сбербанк на российском рынке } \\
\text { ипотечного жилищного кредитования }\end{array}$ & 54,6 & 63,5 & 116,3 \\
\hline $\begin{array}{l}\text { 2. Объем выданных ПАО Сбербанк ипотечных } \\
\text { жилищных кредитов }\end{array}$ & 722,0 & 1121,4 & 155,3 \\
\hline 3. Количество выданных ПАО Сбербанк кредитов & 475,0 & 647,4 & 136,3 \\
\hline
\end{tabular}

Составлено по данным ПАО Сбербанк: [Электронный ресурс]. Режим доступа: http: www.cberbank.ru, свободный

Таблица 4. Анализ структуры ссудной задолженности физических лиц по ипотечному жилищному кредитованию ПАО Сбербанк в 2015-2017 гг., млрд. руб.

\begin{tabular}{|l|c|c|c|c|c|c|}
\hline \multirow{2}{*}{\multicolumn{1}{|c|}{ Показатели }} & \multicolumn{2}{|c|}{2015} & \multicolumn{2}{c|}{2016} & \multicolumn{2}{c|}{2017} \\
\cline { 2 - 7 } & $\begin{array}{c}\text { непросро- } \\
\text { ченные }\end{array}$ & $\begin{array}{c}\text { просро- } \\
\text { ченные. }\end{array}$ & $\begin{array}{c}\text { непросро- } \\
\text { ченные }\end{array}$ & $\begin{array}{c}\text { просро- } \\
\text { ченные }\end{array}$ & $\begin{array}{c}\text { непросро- } \\
\text { ченные }\end{array}$ & $\begin{array}{c}\text { просро- } \\
\text { ченные }\end{array}$ \\
\hline $\begin{array}{l}\text { Ипотечное жилищ- } \\
\text { ное кредитование }\end{array}$ & 2431,1 & 123,5 & 2629,7 & 121,2 & 3087,0 & 103,6 \\
\hline Итого за год & \multicolumn{2}{|c|}{2554,6} & \multicolumn{2}{|c|}{2750,9} & \multicolumn{2}{|c|}{3190,6} \\
\hline
\end{tabular}

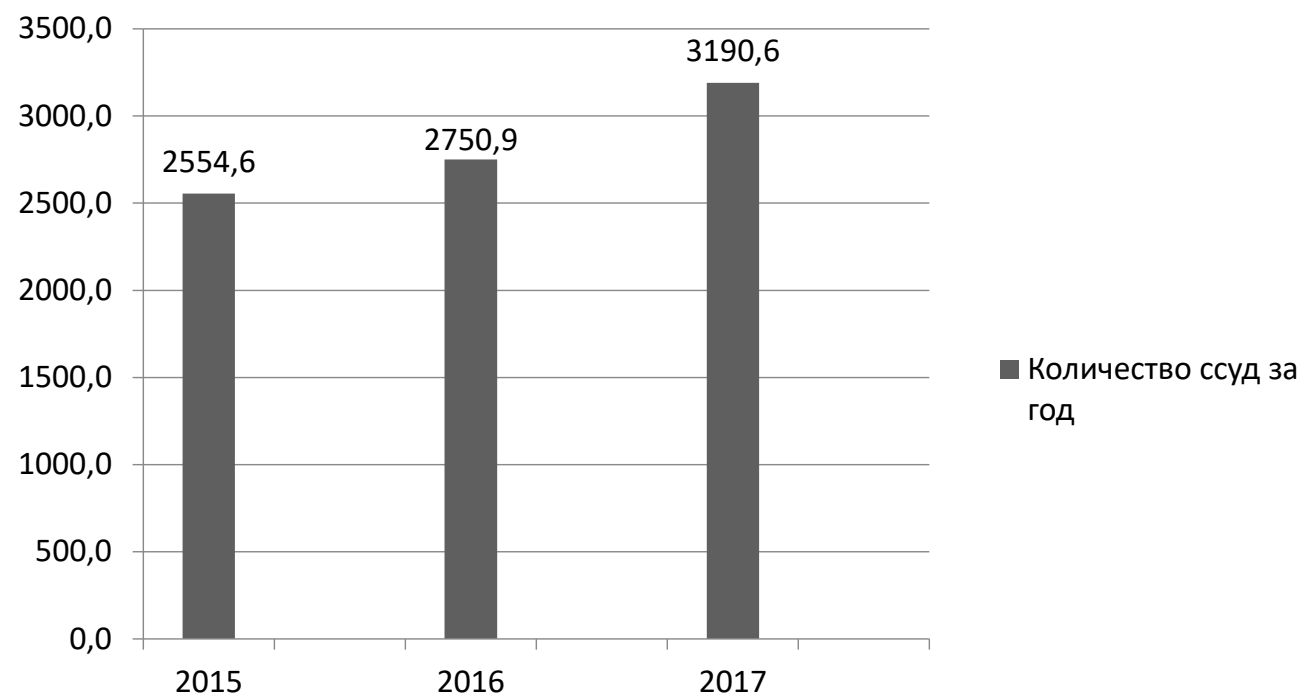

Puc. 1. Объём ссудной задолженности ипотечного жилищного кредитования физических лиц ПАО Сбербанка 2015 - 2017 гг., в млрд. руб. 
Во-вторых, ПАО Сбербанк широкий спектр продуктов ипотечного кредитования.В-третьих, у банка срок выплаты кредита - до 30 лет.

Основное конкурентное преимущество ПАО Сбербанк - это один из крупнейших банков РФ, имеющий значительный опыт в кредитовании и наиболее благонадежную репутацию, предлагающий максимально удобные вариативные условия для своих клиентов. Достоинства МСФО, перед национальными стандартами в отдельных странах, проявляются в:

- четкой экономической логике;

• обобщении лучшей современной мировой практики в области учета;

- простоте восприятия для пользователей финансовой информации во всем мире.

Данные финансовой отчетности по МСФО дают возможность рассмотреть более подробно рынок ипотечного жилищного кредитования по сравнению с данными бухгалтерской отчетности по российским стандартам. В финансовой отчетности представлены показатели реструктурированных и модифицированных кредитов, т.е. в отношении которых было проведено вынужденное изменение условий.

\section{Библиографический список}

1. Парамонова Т.В. 2004 год - год перехода российского банковского сектора на подготовку финансовой отчетности по международным стандартам //Деньги и кредит. - 2004. - № 1.- c. 3.

2. Дарякин А.А. Международные стандарты финансовой отчетности в деятельности российских коммерческих банков //Диссертация на соискание.......Казань, 2010 - с. 15.

3. Березов М. Ю. Подготовка и использование отчетности по МСФО для управления банком// Банковские услуги. $-2002 .-$ № $1-$ с. 23.$)$ 